\title{
Effect of Ownership Structure on Bank Diversification and Risk-Taking Behavior in Bangladesh
}

\author{
Syed MOUDUD-UL-HUQ ${ }^{1}$, Tanmay BISWAS ${ }^{2}$, Brishti CHAKRABORTY ${ }^{3}$, Md. Al AMIN ${ }^{4}$ \\ Received: August 01, 2020 Revised: October 05, 2020 Accepted: October 15, 2020
}

\begin{abstract}
This study empirically examines the effect of ownership structure on bank diversification and risk-taking behavior. The population of this study is based on all commercial banks listed in Bangladesh. Thirty-two conventional commercial banks were randomly selected from thirty-three conventional banks for this study. Data was collected from the annual reports of the concerned banks from 2000 to 2017 . To analyze the data, we had applied the two-stage least squares (2SLS) estimator. The results of the analysis show that ownership structure i.e. managerial ownership, institutional ownership, general public ownership, and ownership concentration have a significant negative impact on bank diversification. On the other hand, institutional ownership, managerial ownership, and general public ownership have a significant positive impact on Z-score, and ownership concentration has an insignificant but positive impact on the Z-score of banks in Bangladesh. Therefore, the study opposes the benefits of diversification and promotes ownership structure which is capable of ensuring better financial stability by reducing the probability of risk. The policy-makers especially, Bangladesh banks should evaluate the fact of this study to issue guidelines on corporate governance, bank diversification, and risk-taking behavior of commercial banks.
\end{abstract}

Keywords: Ownership Structure, Diversification, Bank Risk, Ownership Concentration, Two-stage Least Squares

JEL Classification Code: G10, G21, C25

\section{Introduction}

The banking sector plays a significant role in uplifting the country's economy. A sound and established banking system are requisite for the sustainable economic development of a country. In the last few decades, banks have been facing many challenges after the third financial crisis and it is

${ }^{1}$ First Author and Corresponding Author. Department of Accounting, Mawlana Bhashani Science and Technology University, Tangil, Bangladesh [Postal Address: Santosh, Tangail-1902, Bangladesh] Email: moudud_cu7@mbstu.ac.bd

${ }^{2}$ Department of Accounting, Mawlana Bhashani Science and Technology University, Tangil-1902, Bangladesh.

Email: tbiswas.actg@gmail.com

${ }^{3}$ Department of Accounting, Mawlana Bhashani Science and Technology University, Tangil-1902, Bangladesh.

Email: brishtichakraborty.bba.mbstu@gmail.com

${ }^{4}$ Department of Accounting, Mawlana Bhashani Science and Technology University, Tangil-1902, Bangladesh.

Email: amin199215@gmail.com

(C) Copyright: The Author(s)

This is an Open Access article distributed under the terms of the Creative Commons Attribution Non-Commercial License (https://creativecommons.org/licenses/by-nc/4.0/) which permits unrestricted non-commercial use, distribution, and reproduction in any medium, provided the original work is properly cited. crucial to take potential and logical actions to overcome this difficult and insecure time and enhance their performance. The significance of banks in the economy and their capacity to cause threats necessitates framing guidelines. Furthermore, Heid, Porath, and Stolz (2003) suggested that capital guidelines are most of the times are guided by the suspicion of deft conduct of banks. The attributes of banks, for example, high influence, contorted data, feeble nursing by the contributors, and restricted obligation incited enormous investors to expand bank risk-taking guidelines.

The banking system largely depends on how well it manages risk. But managing risk is complicated as management depends on different ownership structures too. Zeitun and Gang Tian (2007) discussed the importance of ownership structure in the context of performance and finance literature. However, evidence of the effectiveness of ownership is mixed. Laeven and Levine (2007) had found a higher risk of concentered ownership. On the one hand, performance and risk-taking behavior depend on the identity of the controlling shareholder (Ongore, 2011).

Although large shareholders may exercise their rights to pursue benefit at the cost to the minority shareholder (Shleifer, La Porta, \& Lopez-De-Silanes, 1999). The new circumstances, in which banks manage and the specificities 
of finance, highlight the failing in the imposition of risks and vulnerabilities. On the one hand, the conventional banking system gives loans to different types of people, customers, and other institutions. As a result, the banking system charges interest and earns money. Based on the ASEAN-5 emerging economies, Moudud-Ul-Huq et al. (2018) reveal the benefit of bank diversification in terms of risk and performance. It also persists in the following studies (Moudud-Ul-Huq, 2019a; Moudud-Ul-Huq et al., 2020).

In the current, situation risk management plays a significant role in the banking industry. Today, banks and other financial institutions obverse a lot of risk in their daily business operations such as credit risk or default risk, interest rate fluctuation risk, liquidity risk, foreign currency exchange risk, other types of risk which is the main impediment of a banking system. Therefore, an effective and efficient risk management practice is exceptionally needed for bank survival and success.

Constructs relating to financial risk measurement factors are liability structure ratio, quick ratio, return on assets, total asset turnover, accounts receivable turnover, net assets ratio, and fixed assets ratio; but there is a difference between the impact of these factors on financial risk in state-owned enterprises listed on the Vietnam stock market and non-state enterprises (Dang et al., 2020).

There are different types of ownership structures in the banking industry such as they can be a conventional commercial bank and Islamic bank, they can be in managerial ownership banks, institutional ownership commercial banks, general public commercial banks, and can be ownership concentration commercial banks. State ownership and ownership by foreign investor-oriented ownership were positively and significantly associated with the systemic risk, whereas domestic investor-oriented ownership has a reverse effect on the systematic risk of listed companies in Vietnam (Thuy UV, Phan, \& Dang, 2019). Diversification attempts significantly improved the performance of Sri Lankan banks and bank's performance is positively and significantly associated with diversification. More diversified banks are more profitable banks (Pisedtasalasai \& Edirisuriya, 2020).

Therefore, there is a subsequent need to have an insight into how a bank's ownership structure affects investment decisions, reduction, and risk of lack of money in the context of banking (Tang, Alam, Lokan, \& Abbass, 2012). However, this study extends the scope of the current literature through the following contributions. First, it shows the effect of diverse ownership structure on bank diversification to test whether there is any heterogeneous impact of ownership structure. Second, it shows the impact of ownership structure on risk-taking behavior. Third, it extends the previous literature by introducing bank diversification as a dependent variable. Finally, this study underpins the effect of ownership structure on bank diversification and risk-taking behavior in the context of a developing economy like Bangladesh.

Now the question is how the different types of ownership affect bank diversification and risk-taking behavior. The main objectives of these observations are to find out the impact of different types of ownership structure on bank diversification and bank risk-taking behavior in Bangladesh.

The reminder sections of this research paper are designed as followed: Section-2: literature review and hypotheses development. Section-3: research framework and econometric modeling. Section-4: findings and analysis and finally, Section-5: conclusions and recommendations.

\section{Literature Review and Hypotheses Development}

For the ease of discussion, we have categorized this section as: (i) the relationship between ownership structure and bank diversification; (ii) the relationship between ownership structure and bank risk-taking behavior; (iii) development of conceptual framework; and (iv) development of hypotheses.

\subsection{Ownership Structure and Bank Diversification}

For the ease of our discussion, we have arranged this section by emphasizing the relationship between different types of ownership and bank diversification.

\section{Institutional ownership and bank diversification}

Among the very few instances, Deng, Elyasiani, and Jia (2013) described institutional ownership as a risk-averse attribute that boosts the organization benefits by way of diversification strategy. But the adoption of a diversification strategy also depends on diverse ownership patterns (Ramaswamy, Li, \& Veliyath, 2002).

\section{Managerial ownership and bank diversification}

Yoshikawa and Phan (2005) argued against managerial ownership, as the higher stakes of such ownership reduce the probability of product diversification. Chen and Yu (2012) point out the positive outcomes from the diversification that entails short-term firm performance and no such connection with mid-term firm performance.

\section{General public ownership and bank diversification}

General public ownership refers to the ownership of industry, enterprise, or asset by the public body performing for a community as against an individual or a private party. It is also called state ownership. Pashigian (1976) shows that increase in automobile ownership is the reason for reduced profits and public ownership. Besides, Chau and Gray (2002) showed that the extent of outside ownership is positively associated with voluntary disclosures. 
Ownership concentration and bank diversification

Ownership concentration is considered as the key to making a strategic decision (Demsetz \& Lehn, 1985). Therefore, bank diversification also relies on concentrated ownership. However, the possible outcomes are yet to be explored

\subsection{Ownership Structure and Risk-Taking}

For the ease of our discussion, we have arranged this section by emphasizing the relationship between different types of ownership and risk.

Institutional ownership and bank risk-taking

There was a dearth of literature in the context of institutional ownership and risk. But nowadays, the readership and research interest are growing up. But the evidence in connection is mixed for few studies (Dennis \& Strickland, 2002; Sias, 1996; Xu \& Malkiel, 2003) which posit and find the positive relationship between institutional ownership and stock return unpredictability. Sias (1996) presumes that an expansion in institutional ownership level in firms increases stock instability. The contention clarifies the positive relationship that educated institutional financial specialists are preferred over other individual speculators. Then again, different studies contend that there is a negative relationship between institutional ownership and stock unpredictability. This affirms that institutional financial specialists have better data over individual speculators and consequently, their exchanges will cover more subtle content. Further, an expansion in the data substance of stock costs is related to the decrease of the difference of stock returns, thereby diminishing stock return unpredictability (Vo, 2016).

\section{Managerial ownership and bank risk-taking}

Jensen and Ruback (1983) and Shleifer et al. (1999) demonstrate that higher managerial ownership could relieve organization issues. Lee (2004) discovered that there is a huge significance of managerial ownership. Saunders, Strock, and Travlos (1990) found out that the extent of managerial ownership has more risk-taking behavior than lower managerial ownership while Cebenoyan, Cooperman, and Register (1999) demonstrated that provision with higher managerial ownership shows unbeneficial risk-taking behavior. Chun, Nagano, and Lee (2011) reasoned that improved managerial ownership expands the risk of Japanese banks while it does not add any risk to the banks in Korea.

\section{General public ownership and bank risk-taking}

General public owners are one of the key determinants of bank risk-taking behavior. Whether in connection with the higher stakes of general public ownership, the aptitude of taking a risk might be different from other ownership as this type of ownership has no self-interest and no probability of the alignment to the administration. Hence, we predict that the impact of general public ownership on risk is negative.

\section{Ownership concentration and bank risk-taking}

Ownership concentration does not expressively affect a bank's profitability. Normally a higher ownership concentration is associated with better loan quality, lower asset risk, and lower insolvency risk. Some studies (Martínez \& Ramírez, 2011; Saunders, Strock, \& Travlos, 1990) find a positive relationship between ownership concentration and bank risk-taking behavior. Burkart, Gromb, \& Panunzi (1997) provides a negative relation between ownership concentration and bank risk-taking.

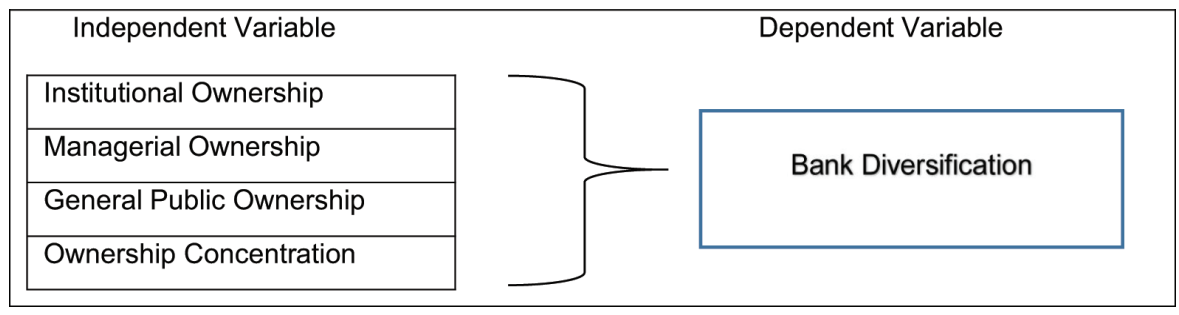

Figure 1: Relationship between Ownership Structure and Bank Diversification

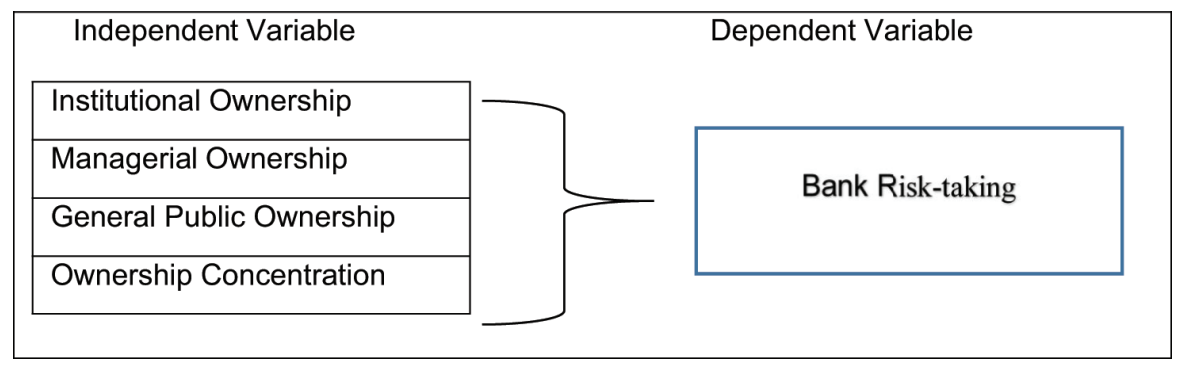

Figure 2: Relationship between Ownership Structure and Bank Risk-taking 


\subsection{Conceptual Framework}

We use two figures (Fig.1 and Fig.2) to exhibit the effect of ownership structure on bank diversification and risk-taking behavior. Where Fig.1 displays the effect of ownership structure on bank diversification and Fig.2 reflects the influence of ownership structure on the bank's risk behavior.

\subsection{Development of Hypotheses}

Based on the previous studies (section 2.1 and 2.2), we posit the following hypotheses for this study.

$\boldsymbol{H}_{1}$ : there is a diverse impact of ownership structure on bank diversification.

$\boldsymbol{H}_{2}$ : there is a diverse impact of ownership structure on bank risk-taking behavior.

\section{Research Framework and Econometric Modeling}

\subsection{Population and Sample}

The population of this study is based on all commercial banks listed in Bangladesh. There are thirty-three conventional commercial banks listed in Bangladesh. Thirty-two conventional commercial banks were randomly selected from thirty-three conventional banks for this study. Data was collected from the annual reports of the concerned banks from 2000 to 2017.

\subsection{Definition of Control Variables}

Besides, the dependent variables (bank diversification and risk-taking), the main exogenous variable (ownership structure), we also use some bank-level control variables which have been discussed briefly in Table 1 .

Table 1: Definition of variables

\begin{tabular}{|c|c|c|c|}
\hline Variables & Measurement of variables. & Predated signs & Source \\
\hline Diversification & $\begin{array}{l}\text { Non- interest income to total } \\
\text { operating income. }\end{array}$ & $+/-$ & $\begin{array}{l}\text { (Berger \& Ofek, 1995; Deng et al., } \\
\text { 2013; Laeven \& Levine, 2007; Lloyd, } \\
\text { Modani, \& Hand, 1987) }\end{array}$ \\
\hline Z-Score & $\begin{array}{l}\text { Indicator of the insolvency risk, } \\
\text { measured as the mean of return on } \\
\text { assets plus the capital asset ratio } \\
\text { (equity capital/total assets) divided } \\
\text { by the standard deviation of asset } \\
\text { returns. (ROA+E/A)/ ( } \sigma \text { ROA) }\end{array}$ & - & $\begin{array}{l}\text { (Dong, Meng, Firth, \& Hou, 2014; } \\
\text { Migliardo \& Forgione, 2018; Moudud- } \\
\text { Ul-Huq, 2018, 2019b; Moudud-Ul- } \\
\text { Huq et al. 2018, Moudud-Ul-Huq et } \\
\text { al. 2020, Srairi, 2013; Zhang \& Jiang, } \\
\text { 2018) }\end{array}$ \\
\hline $\begin{array}{l}\text { Institutional Ownership } \\
\text { (INO) }\end{array}$ & $\begin{array}{l}\text { The proportion of equity held by } \\
\text { the financial and non-financial } \\
\text { companies. }\end{array}$ & $+/-$ & $\begin{array}{l}\text { (Bushee, 1998; Dechow, Sloan, \& } \\
\text { Sweeney, 1996; Gompers \& Metrick, } \\
\text { 2001; Neubaum \& Zahra, 2006; } \\
\text { Stapledon \& Stapledon, 1997) }\end{array}$ \\
\hline $\begin{array}{l}\text { Managerial Ownership } \\
\text { (MNO) }\end{array}$ & $\begin{array}{l}\text { The proportion of equity held by } \\
\text { the board of directors and other } \\
\text { managerial persons. }\end{array}$ & - & $\begin{array}{l}\text { (Cebenoyan, Cooperman, \& Register, } \\
\text { 1999; Jensen \& Ruback, 1983; Lee, } \\
\text { 2004; Saunders et al., 1990; Shleifer } \\
\text { \& Vishny, 1997; Stulz, 1990) }\end{array}$ \\
\hline $\begin{array}{l}\text { General Public } \\
\text { Ownership (GPO) }\end{array}$ & $\begin{array}{l}\text { Equity percentage participation by } \\
\text { the general public. }\end{array}$ & + & $\begin{array}{l}\text { (Chau \& Gray, 2002; Pashigian, } \\
\text { 1976) }\end{array}$ \\
\hline $\begin{array}{l}\text { Ownership } \\
\text { Concentration (CONC) }\end{array}$ & $\begin{array}{l}\text { Equity percentage participation by } \\
\text { the largest shareholder of the bank. }\end{array}$ & $+/-$ & $\begin{array}{l}\text { (Anderson \& Fraser, 2000; Burkart } \\
\text { et al., 1997; Gorton \& Rosen, 1995; } \\
\text { lannotta, Nocera, \& Sironi, 2007; } \\
\text { Martínez \& Ramírez, 2011) }\end{array}$ \\
\hline Bank Size (BS) & Log of total assets & - & $\begin{array}{l}\text { (Bokpin, 2013; Moudud-Ul-Huq, } \\
\text { 2020; Srairi, 2013; Su, 2010; Zhang } \\
\text { \& Jiang, 2018; Zheng \& Moudud-Ul- } \\
\text { Huq, 2017) }\end{array}$ \\
\hline Leverage (LEV) & Total liabilities to total equity & + & (Moudud-Ul-Huq et al., 2018) \\
\hline Lending (LEN) & Net loans to total assets & $+/-$ & (Haque \& Shahid, 2016) \\
\hline e & Error term & & \\
\hline
\end{tabular}




\subsection{Regression Equations}

To examine the effect of ownership structure on bank diversification and risk-taking, we develop the regression equations as:

Diversification $=\alpha_{0}+\alpha_{1} \mathrm{INO}+\alpha_{2} \mathrm{MNO}+\alpha_{3} \mathrm{GPO}+$ $\alpha_{4} \mathrm{CONC}+\alpha_{5} \mathrm{LEN}+\alpha_{6} \mathrm{LEV}+\alpha_{7} \mathrm{BS}+\mathrm{e} \ldots \ldots \ldots$

$\mathrm{Z}$-Score $=\beta_{0}+\beta_{1} \mathrm{INO}+\beta_{2} \mathrm{MNO}+\beta_{3} \mathrm{GPO}+\beta_{4} \mathrm{CONC}+$ $\beta_{5} \mathrm{LEN}+\beta_{6} \mathrm{LEV}+\beta_{7} \mathrm{BS}+\mathrm{e} \ldots \ldots$

There are two dependent variables, which have been used in the above equations. Bank diversification and bank risktaking behavior are the dependent variables for Eq.1 and Eq.2 respectively. Ownership structure is the main explanatory variable which categorizes as institutional ownership (INO), managerial ownership(MNO), general public ownership(GPO), and concentrated ownership (CONCE) respectively. Lending (LEN), leverage (LEV), and bank size (BS) respectively are a part of control variables. e indicates the error term. $\boldsymbol{\alpha}, \boldsymbol{\beta}$ are the coefficient of repressors. To estimate the above equations, we rely on the two-stage least squares (2SLS) approach as it can address heteroscedasticity and endogeneity issues.

\section{Empirical Result and Analysis}

In this section, we analyze the descriptive statistics in which we get the mean, standard deviation, minimum, and maximum value of the variables. Later, correlation analysis helps us to find the relationship between dependent and independent variables. Finally, regression analysis helps us to find the causal effect between dependent and independent variables, especially, it shows the effect of ownership structure on bank diversification and risk-taking behavior.

\subsection{Descriptive Statistics}

Table 2 shows summary statistics for the key variables used in this study. In this study, we consider 32 banks from
Bangladesh for the period between 2000 and 2017. There are two dependent variables such as bank diversification and risk-taking behavior. In this study, we also consider the main exogenous and few control variables. The main independent variables are managerial ownership (MNO), institutional ownership (INO), general public ownership (GPO), and ownership concentration (CONC). This shows that ownership concentration is a common practice, with institutional ownership being very powerful amongst the banks. We also find that managerial ownership also has a dominant part in the banking sector. We also indicate some control variables that make the measurement very clear. These variables are lending (LEN), leverage (LEV), and bank size (BS). In this descriptive analysis, we find the mean, standard deviation, maximum and minimum values of variables including dependent, main independent, and control variables.

Table 2 shows the summary of statistic for the variables which have been used in the econometric models. The mean of diversification is 0.5875 . It has a maximum value of 2.24 and a minimum value of 0.10 and the SD for diversification is 0.22240 . The mean of Z-score (second dependent variable) is 18.7808. It has a maximum value of 51.18 and a minimum value of -20.82 . The SD for Z-score is 12.18006 . The mean of institutional ownership is 17.3806 . It has a maximum value of 88 $\&$ a minimum value of 0 and the SD of institutional ownership is 10.70189. The mean of managerial ownership is 40.7906. It has a maximum value of 100 and a minimum value of 0 and the $\mathrm{SD}$ of managerial ownership is 20.00111. The mean value of general public ownership is 36 . 9673. It has a maximum value of 95.77 and a minimum value of 0 and the SD of general public ownership is 21.45534. The mean of ownership concentration is 314.0892. It has a maximum value of 6738.94 and a minimum value of 0.25 and the SD value of ownership concentration is 479.18304. For control variables, the mean of lending is 0.6574 . It has a maximum value of 0.84 and a minimum value of 0.05 and the SD of lending is 0.09229 . The mean of leverage is 0.09231 , the minimum and maximum value range from 0.05 to 1.13 and the SD is 0.09430 . The mean of bank size is 11.3164 . The minimum and maximum value range from 0.05 to 14.85 and the SD of bank size is 1.21108 .

Table 2: Descriptive statistics

\begin{tabular}{|l|c|c|c|c|c|}
\hline Variables & $\mathbf{N}$ & Minimum & Maximum & Mean & Std. Deviation \\
\hline Diversification & 530 & .10 & 2.24 & .587 & .222 \\
\hline Z score & 530 & -20.82 & 51.18 & 18.780 & 12.180 \\
\hline INO & 530 & 0.00 & 88.00 & 17.380 & 10.701 \\
\hline MNO & 530 & 0.00 & 100.00 & 40.790 & 20.001 \\
\hline GPO & 530 & 0.00 & 95.77 & 36.967 & 21.455 \\
\hline CONC & 530 & .25 & 6738.94 & 314.089 & 479.183 \\
\hline LEN & 530 & .05 & .84 & .657 & .923 \\
\hline LEV & 530 & .05 & 1.13 & 11.316 & .094 \\
\hline BS & 530 & .05 & 14.85 & & \\
\hline Valid N (list wise) & 530 & & & & \\
\hline
\end{tabular}


Table 3: Correlation Analysis

\begin{tabular}{|c|c|c|c|c|c|c|c|c|c|}
\hline & Diversification & Z score & INO & MNO & GPO & CONC & LED & LEV & BS \\
\hline Diversification & 1 & & & & & & & & \\
\hline Z score & $-.364^{* *}$ & 1 & & & & & & & \\
\hline INO & .019 & $.108^{*}$ & 1 & & & & & & \\
\hline MNO & -.020 & $-.136^{* *}$ & $-.093^{*}$ & 1 & & & & & \\
\hline GPO & $-.183^{* *}$ & $.250^{\star *}$ & $-.315^{* *}$ & $-.556^{* *}$ & 1 & & & & \\
\hline CONC & $-.085^{*}$ & $.090^{*}$ & .016 & $-.103^{*}$ & .054 & 1 & & & \\
\hline LED & $-.386^{* *}$ & $.261^{\star \star}$ & -.050 & -.020 & $.158^{* *}$ & $.094^{*}$ & 1 & & \\
\hline LEV & .053 & -.060 & .062 & $.110^{*}$ & $-.140^{* *}$ & $-.125^{\star *}$ & .065 & 1 & \\
\hline BS & $.168^{* *}$ & -.030 & $.105^{\star}$ & $-.111^{*}$ & $-.196^{\star *}$ & $.479^{* *}$ & $-.158^{* *}$ & $-.143^{* *}$ & 1 \\
\hline
\end{tabular}

Table 4: Regression Analysis

\begin{tabular}{|c|c|c|}
\hline \multicolumn{2}{|l|}{ Variables } & Diversification \\
\hline \multirow{2}{*}{\multicolumn{2}{|c|}{ INO }} & $-0.001^{* *}$ \\
\hline & & $(-2.065)$ \\
\hline \multirow{2}{*}{ MNO } & & $-0.001^{* * *}$ \\
\hline & & $(-2.918)$ \\
\hline \multirow{2}{*}{ GPO } & & $-0.002^{* * *}$ \\
\hline & & $(-3.517)$ \\
\hline \multirow{2}{*}{ CONC } & & $-5.19^{\star *}$ \\
\hline & & $(-2.426)$ \\
\hline \multirow{2}{*}{ LEN } & & $-0.809^{* * *}$ \\
\hline & & $(-8.232)$ \\
\hline \multirow{2}{*}{ LEV } & & $0.178^{* *}$ \\
\hline & & $(-1.886)$ \\
\hline \multirow{2}{*}{ BS } & & $0.024^{* * *}$ \\
\hline & & $(-2.707)$ \\
\hline \multirow{2}{*}{ C } & & $0.873^{* * *}$ \\
\hline & & $(-5.025)$ \\
\hline \multicolumn{3}{|c|}{$\begin{array}{ll}\text { Adjusted R-squared } & 0.192\end{array}$} \\
\hline \multirow{3}{*}{$\begin{array}{l}\text { Number of observations } \\
\text { Number of Instrument } \\
\text { Number of banks }\end{array}$} & 530 & \\
\hline & 9 & \\
\hline & 32 & \\
\hline
\end{tabular}

\subsection{Correlation Analysis}

Table 3 shows the correlation matrix for the dependent, independent, and control variables that have been used in the regression model. In the correlation analysis, we find some positive relation with dependent variables, independent variables, and control variables. It also shows the negative relationship with independent, dependent, and control variables. In this correlation analysis, Table 3 shows the relationship with $10 \%$ and a $5 \%$ level of significance. Therefore, it shows some strong, weak relationships with the variables. Correlation co-efficient below -0.556 indicates that weaker relationships exist among the independent variables (GPO \& MNO). The correlation between bank 
size and ownership concentration is 0.479 that indicates a weak relationship with them. However, other variables' relationship shows a positive or negative and significant relationship.

Table 3 also shows that Z-score has a negative relationship -(0.364) with diversification, which means that if risk increases, then the stability of the bank decreases, and when risk decreases, the stability increases. INO has a positive (0.108) relationship with Z-score, which means that if institutional ownership increases, then the risk of the bank increases, and when institutional ownership decreases, the risk decreases. It also shows no significant relation with diversification. MNO shows a negative $(-0.20)$ relationship with diversification and also shows a negative $(-0.136)$ relationship with Z-score, which means that if managerial ownership increases, then the risk of the bank decreases, and when managerial ownership decreases, the risk increases. GPO shows a negative $(-0.183)$ relationship with diversification, which means that if the general public ownership increases, then the diversity of the bank decreases, and when general public ownership decreases, the diversity increases; however, there is a positive relationship (0.250) with Z-score, which means that if the general public ownership increases then the risk of the bank increases, and when general public ownership decreases, the risk also decreases. CONC shows a negative $(-0.085)$ relationship with diversification, which means that if the ownership concentration increases, then the diversity of the bank decreases, and when risk decreases, the diversity increases and has a positive relationship (0.090) with Z-score, which means that if the ownership concentration increases then the risk of the bank increases, and when ownership concentration decreases, the risk decreases. LEN has a negative (-0.386) relationship with diversification. LEV and BS show positive $(0.053)$ and $(0.168)$ respectively with diversification, and also show negative $((-0.060)$ and $(-0.030))$ relation with Z-score.

\subsection{Regression Analysis}

Table 4 shows the regression analysis of variables. In this analysis, the dependent variable is diversification and the independent variables are managerial ownership, institutional ownership, general public ownership, and ownership concentration. The control variables are lending, leverage, and bank size. It shows the positive or negative impact of ownership structure on bank diversification. It also provides a significant impact on other variables.

The after-effect of relapse examination utilizing diversification ((Berger \& Ofek, 1995) as the dependent variable is given in Table 4 . It shows that the estimation of F-Statistics is significant and signifies the fitness of the model, while the coefficient of determination is $19.20 \%$ which shows the explanatory power of independent variables to explain the dependent variable. All the independent variables i.e. institutional ownership $(5 \%$ level of significance), managerial ownership ( $1 \%$ level of significance), general public ownership (1\% level of significance), and ownership concentration (5\% level of significance) have a significant negative impact on bank diversification. This is similar to many studies (Deng et al., 2013; Laeven \& Levine, 2007). It shows that banks in Bangladesh with a higher concentration of ownership disfigure bank diversification. These studies also recommend that with higher managerial ownership, higher institutional ownership, and higher general public ownership decline bank diversification. The leverage and bank size have a significant positive impact on bank diversification. Therefore, the outcomes include the benefit from diversification with higher engagement of diverse ownership structure along with bank size and leverage policy, which also promotes bank diversification.

Table 5 shows the regression analysis based on the effect of ownership structure on risk-taking where Z-score is a dependent variable. Independent variables are managerial ownership, institutional ownership, general public ownership, and ownership concentration. The control variables lending, leverage, and bank size are also used in this analysis. This analysis also shows the positive and negative impact and significant impact of the variables.

Similar to the results of Table 4, the model is also a fit as a whole for Table 5 while the coefficient of determination is $14.90 \%$ and implies the explanatory power of the model. All the independent variables i.e. institutional ownership (1\% level of significance), managerial ownership $(10 \%$ level of significance), and general public ownership (1\% level of significance) have a significant positive impact on $\mathrm{Z}$-score that inversely relates with bank risk. Impressively, the effect of diverse ownership structure on bank financial stability (inverse of risk) is positive, implying that a higher number of different ownerships, boost the bank's financial stability by reducing the risk. These results partly confirm the following studies e.g., (Chou \& Lin, 2011; Iannotta, Nocera, \& Sironi, 2007; Chun, Nagano, \& Lee, 2011). It shows that banks in Bangladesh with higher ownership structure improves the bank's financial stability. Unfortunately, there is no significant effect of ownership concentration on risk. Among the control variables, lending has an crucial effect on bank financial stability by reducing the probability of risk while there is no other significant effect from control variables such as leverage and bank size. 
Table 5: Regression Analysis

\begin{tabular}{|c|c|c|}
\hline Variables & & Z-score \\
\hline \multirow{2}{*}{ INO } & & $0.263^{* * *}$ \\
\hline & & $(-5.141)$ \\
\hline \multirow{2}{*}{ MNO } & & $0.053^{*}$ \\
\hline & & $(-1.657)$ \\
\hline \multirow{2}{*}{ GPO } & & $0.190^{* * *}$ \\
\hline & & $(-5.787)$ \\
\hline \multirow{2}{*}{ CONC } & & 0.000 \\
\hline & & $(-0.697)$ \\
\hline \multirow{2}{*}{ LEN } & & $29.806^{* * *}$ \\
\hline & & $(-5.393)$ \\
\hline \multirow{2}{*}{ LEV } & & -5.764 \\
\hline & & $(-1.082)$ \\
\hline \multirow{2}{*}{ BS } & & 0.361 \\
\hline & & $(-0.715)$ \\
\hline \multirow{2}{*}{ C } & & -13.684 \\
\hline & & $(-1.401)$ \\
\hline $\begin{array}{l}\text { Adjusted R-squared } \\
\text { Number of observations }\end{array}$ & $\begin{array}{c}0.149 \\
530\end{array}$ & \\
\hline $\begin{array}{l}\text { Number of Instrument } \\
\text { Number of banks }\end{array}$ & $\begin{array}{r}9 \\
32\end{array}$ & \\
\hline
\end{tabular}

\section{Conclusions and Recommendation}

This study is about the impact of ownership structure on bank diversification and risk-taking behavior in Bangladesh. Diversification is used as diversity and Z-score is used as a risk-taking variable. While managerial ownership, institutional ownership, general public ownership, and ownership concentrations were taken as the proxies for ownership structure. The results suggested that all the representations of ownership structure i.e. managerial ownership, institutional ownership, general public ownership, and ownership concentration have a significant negative impact on diversification. On the other hand, using Z-score as a proxy for risk-taking, the proxies of institutional ownership, managerial ownership, and general public ownership have a significant positive impact on Z-score, and ownership concentration has an insignificant positive impact on the Z-score of banks in Bangladesh. Therefore, from the results, it suggests the following policy implications. The banking regulators can promote bank financial stability by taking ownership structure into account for formulating strategies. Policymakers also should consider the size of the banks which can be a good motivator for bank diversification. Moreover, they should rethink about the ownership structure to diversify the bank's profitability as the ownership structure may advocate for portfolio diversification. Though the study has many contributions, it faces some limitations. For example, if we could use different control variables separately for two equations, then we would get more interesting outcomes. Moreover, if we could check the robustness by using different alternative measures of diversification, risk-taking, and ownership structure, then it would validate the results better. In connection with this study, one can augment the scope by considering a crosscountry analysis.

\section{References}

Anderson, R. C., \& Fraser, D. R. (2000). Corporate control, bank risk taking, and the health of the banking industry. Journal of Banking \& Finance, 24(8), 1383-1398.

Berger, P. G., \& Ofek, E. (1995). Diversification's effect on firm value. Journal of Financial Economics, 37(1), 39-65. https:// doi.org/10.1016/0304-405X(94)00798-6 
Bokpin, G. A. (2013). Ownership structure, corporate governance and bank efficiency: an empirical analysis of panel data from the banking industry in Ghana. Corporate Governance: The International Journal of Business in Society, 13(3), 274-287. https://mpra.ub.uni-muenchen.de/94665/

Burkart, M., Gromb, D., \& Panunzi, F. (1997). Large shareholders, monitoring, and the value of the firm. The Quarterly Journal of Economics, 112(3), 693-728.

Bushee, B. J. (1998). The influence of institutional investors on myopic R\&D investment behavior. Accounting Review, 73(3), 305-333.

Cebenoyan, A. S., Cooperman, E. S., \& Register, C. A. (1999). Ownership structure, charter value, and risk-taking behavior for thrifts. Financial Management, 28(1), 43-60. https://www. jstor.org/stable/3666116

Chau, G. K., \& Gray, S. J. (2002). Ownership structure and corporate voluntary disclosure in Hong Kong and Singapore. The International Journal of Accounting, 37(2), 247-265.

Chen, C. J., \& Yu, C. M. J. (2012). Managerial ownership, diversification, and firm performance: Evidence from an emerging market. International Business Review, 21(3), 518534.

Dang, H. T., Phan, D. T., Nguyen, H. T., \& Thi Hoang, L. H. (2020). Factors affecting financial risk: evidence from listed enterprises in Vietnam. Journal of Asian Finance, Economics and Business, 7(9), 11-18. https://doi.org/10.13106/jafeb.2020.vol7.no9.011

Dechow, P. M., Sloan, R. G., \& Sweeney, A. P. (1996). Causes and consequences of earnings manipulation: An analysis of firms subject to enforcement actions by the SEC. Contemporary Accounting Research, 13(1), 1-36.

Demsetz, H., \& Lehn, K. (1985). The structure of corporate ownership: Causes and consequences. Journal of Political Economy, 93(6), 1155-1177.

Deng, S., Elyasiani, E., \& Jia, J. (2013). Institutional ownership, diversification, and riskiness of bank holding companies. Financial Review, 48(3), 385-415. https://doi.org/10.1111/ fire. 12008

Dennis, P. J., \& Strickland, D. (2002). Who blinks in volatile markets, individuals or institutions? The Journal of Finance, 57(5), 1923-1949. https://doi.org/10.1111/0022-1082.00484

Dong, Y., Meng, C., Firth, M., \& Hou, W. (2014). Ownership structure and risk-taking: Comparative evidence from private and state-controlled banks in China. International Review of Financial Analysis, 36, 120-130.

Gompers, P. A., \& Metrick, A. (2001). Institutional investors and equity prices. The Quarterly Journal of Economics, 116(1), 229-259.

Gorton, G., \& Rosen, R. (1995). Corporate control, portfolio choice, and the decline of banking. The Journal of Finance, 50(5), 1377-1420.

Haque, F., \& Shahid, R. (2016). Ownership, risk-taking and performance of banks in emerging economies: Evidence from
India. Journal of Financial Economic Policy, 8(3), 282-297. https://doi.org/10.1108/JFEP-09-2015-0054

Iannotta, G., Nocera, G., \& Sironi, A. (2007). Ownership structure, risk and performance in the European banking industry. Journal of Banking \& Finance, 31(7), 2127-2149.

Jensen, M. C., \& Ruback, R. S. (1983). The market for corporate control: The scientific evidence. Journal of Financial Economics, 11(1), 5-50. https://doi.org/10.1016/0304405X(83)90004-1

Laeven, L., \& Levine, R. (2007). Is there a diversification discount in financial conglomerates? Journal of Financial Economics, 85(2), 331-367.

Lee, S. W. (2004). Regulation, corporate control and bank risk taking. Corporate Ownership and Control, 1(4), 108-117.

Lloyd, W. P., Modani, N. K., \& Hand, J. H. (1987). The effect of the degree of ownership control on firm diversification, market value, and merger activity. Journal of Business Research, 15(4), 303-312.

Martínez, C., \& Ramírez, M. (2011). Ownership structure and risk at Colombian banks. Serie Documentos de Trabajo, (91).

Migliardo, C., \& Forgione, A. F. (2018). Ownership structure and bank performance in EU-15 countries. Corporate Governance: The International Journal of Business in Society, 18(3), 509530.

Moudud-Ul-Huq, S. (2018). Banks' capital buffers, risk, and efficiency in emerging economies: are they counter-cyclical? Eurasian Economic Review, 1-26. https://doi.org/10.1007/ s40822-018-0121-5

Moudud-Ul-Huq, S. (2019a). Can BRICS and ASEAN-5 emerging economies benefit from bank diversification? Journal of Financial Regulation and Compliance, 27(1), 43-69.

Moudud-Ul-Huq, S. (2019b). The impact of business cycle on banks' capital buffer, risk and efficiency: A Dynamic GMM approach from a developing economy. Global Business Review. https://doi.org/ 10.1177/0972150918817382

Moudud-Ul-Huq, S., Akter, R., Biswas, T., \& Lima, R. P. (2020). Impact of bank's ownership structure on risk and efficiency: Evidence from Bangladesh. International Journal of Financial Engineering, 7(3). https://doi.org/10.1142/ S2424786320500334

Moudud-Ul-Huq, S. (2020). Does bank competition matter for performance and risk-taking? empirical evidence from BRICS countries. International Journal of Emerging Markets. https:// doi.org/10.1108/IJOEM-03-2019-0197

Moudud-Ul-Huq, S., Ashraf, B. N., Gupta, A. D., \& Zheng, C. (2018). Does bank diversification heterogeneously affect performance and risk-taking in ASEAN emerging economies? Research in International Business and Finance, 46, 342-362.

Moudud-Ul-Huq, S., Zheng, C., Gupta, A. D., Hossain, S. K. A., \& Biswas, T. (2020). Risk and performance in emerging economies: do bank diversification and financial 
crisis matter? Global Business Review, 1-27. https://doi. org/10.1177/0972150920915301

Neubaum, D. O., \& Zahra, S. A. (2006). Institutional ownership and corporate social performance: The moderating effects of investment horizon, activism, and coordination. Journal of Management, 32(1), 108-131. https://doi.org/ $10.1177 / 0149206305277797$

Ongore, V. O. (2011). The relationship between ownership structure and firm performance: An Empirical analysis of listed companies in Kenya. African Journal of Business Management, 5(6), 2120-2128. https://doi.org/10.5897/AJBM10.074

Pashigian, B. P. (1976). Consequences and causes of public ownership of urban transit facilities. Journal of Political Economy, 84(6), 1239-1259.

Pisedtasalasai, A., \& Edirisuriya, P. (2020). Diversification and performance of Sri Lankan banks. Journal of Asian Finance, Economics and Business, 7(9), 1-10. https://doi.org/10.13106/ jafeb.2020.vol7.no9.001

Ramaswamy, K., Li, M., \& Veliyath, R. (2002). Variations in ownership behavior and propensity to diversify: A study of the Indian corporate context. Strategic Management Journal, 23(4), 345-358. https://doi.org/10.1002/smj.227

Saunders,A., Strock,E., \& Travlos, N.G.(1990). Ownershipstructure, deregulation, and bank risk taking. The Journal of Finance, 45(2), 643-654. https://doi.org/10.1111/j.1540-6261.1990. tb03709.x

Shleifer, A., La Porta, R., \& Lopez-De-Silanes, F. (1999). Corporate ownership around the world. Journal of Finance, 54(2), 471517. https://doi.org/10.1111/0022-1082.00115

Shleifer, A., \& Vishny, R. W. (1997). A survey of corporate governance. The Journal of Finance, 52(2), 737-783. https:// doi.org/ 10.1111/j.1540-6261.1997.tb04820.x

Sias, R. W. (1996). Volatility and the institutional investor. Financial Analysts Journal, 52(2), 13-20.

Srairi, S. (2013). Ownership structure and risk-taking behaviour in conventional and Islamic banks: Evidence for MENA countries. Borsa Istanbul Review, 13(4), 115-127. https://doi. org/10.1016/j.bir.2013.10.010

Stapledon, G. P., \& Stapledon, G. (1997). Institutional shareholders and corporate governance. Oxford, UK: Oxford University Press.
Stulz, R. (1990). Managerial discretion and optimal financing policies. Journal of Financial Economics, 26(1), 3-27. https:// doi.org/10.1016/0304-405X(90)90011-N

Su, L. D. (2010). Ownership structure, corporate diversification and capital structure: Evidence from China's publicly listed firms. Management Decision, 48(2), 314-339. http://dx.doi. org/10.1108/00251741011022644

Tang, J., Alam, S., Lokan, C., \& Abbass, H. A. (2012). A multiobjective approach for dynamic airspace sectorization using agent based and geometric models. Transportation Research Part C: Emerging Technologies, 21(1), 89-121.

Thuy UV, V. T., Phan, N. T., \& Dang, H. N. (2019). Impacts of Ownership Structure on Systemic Risk of Listed Companies in Vietnam. Journal of Asian Finance, Economics and Business, 7(2), 107-117. https://doi.org/10.13106/jafeb.2020.vol7.no2.107

Vo, X. V. (2016). Does institutional ownership increase stock return volatility? Evidence from Vietnam. International Review of Financial Analysis, 45, 54-61. https://doi.org/10.1016/j. irfa.2016.02.006

Xu, Y., \& Malkiel, B. G. (2003). Investigating the behavior of idiosyncratic volatility. The Journal of Business, 76(4), 613645.

Yoshikawa, T., \& Phan, P. H. (2005). The effects of ownership and capital structure on board composition and strategic diversification in Japanese corporations. Corporate Governance: An International Review, 13(2), 303-312. https:// doi.org/10.1111/j.1467-8683.2005.00424.x

Zeitun, R., \& Gang Tian, G. (2007). Does ownership affect a firm's performance and default risk in Jordan? Corporate Governance: The International Journal of Business in Society, 7(1), 66-82. http://dx.doi.org/10.1108/14720700710727122

Zhang, J., \& Jiang, H. (2018). Capital regulatory pressure, charter value and bank risk-taking: empirical evidence for China. Journal of Financial Regulation and Compliance, 26(1), 170186. https://doi.org/10.1108/JFRC-01-2017-0002

Zheng, C., \& Moudud-Ul-Huq, S. (2017). Banks' capital regulation and risk: Does bank vary in size? Empirical evidence from Bangladesh. International Journal of Financial Engineering, 4(2/3), 1750025. https://doi.org/10.1142/S2424786317500256 